\title{
Students' Academic Performance: An Inquiry into Limited First Class (Honours) Division within the University for Development Studies, Tamale, Ghana
}

\author{
Job Asante \\ University for Development Studies, Tamale, Ghana
}

\begin{abstract}
Globally, academic performance is a key indicator of measuring the quality of an academic institution. This study assesses the factors that influence academic performance of students in public universities in Ghana. Specifically, it was restricted to the University for Development Studies (UDS), Wa Campus. The study adopted the case study design involving 17 respondents with the view to review, process and offer interpretation to data gathered from both secondary and primary sources with the objective to establishing critical factors which have given rise to the limited First Class (Honours) Division among students. The findings reveal that the limited First Class (Honour) Division among students is a reflection of students' performance which is linked to critical input factors such as; poor lesson preparation and delivery, overcrowded lecture halls and poor lecturing schedule time among others. This paper therefore recommends that the Ministry of Education (MOE) should provide UDS with teaching and learning resources. Additionally, UDS administration should provide all necessary infrastructure and equipment for effective practical training for the students. Besides, UDS Management should organise regular workshops and in-service training to introduce all lecturers periodically to more effective teaching strategies. Heads of Department should also monitor and appraise lecturers input by students' performance in respective courses. The University Management should ensure that lecturers teach their respective specialist subjects so that their students will understand what they are taught. This may improve on the number of First Class degree holders produced yearly by UDS.
\end{abstract}

Keywords: Degree Classifications Examination Challenges, Academic Performance, First Cass Students DOI: $10.7176 / \mathrm{JEP} / 10-11-05$

Publication date: April $30^{\text {th }} 2019$

\subsection{BACKGROUND OF STUDY}

Before the coming of the Arabs and Europeans to Africa, the African people had developed their own systems of education; although the systems varied from one community to the other, their goals were often strikingly similar (Sifuna \& Otiende, 1980). This notwithstanding, the UN Convention on the Rights of the Child states that no person shall deprive a child of access to education or any other thing required for his or her development. Education is considered as the bedrock of national development and a major factor in maximizing human resource skills and capabilities.

Globally, governments spend huge amounts of their resources on education. One such benchmark is student performance in school. According to Mankoe (2002), performance refers to the extent to which a worker or student contributes to achieving the goals of his or her institution, and an individual with weak motivation might perform well owing to some chance factor that boosts performance. Academic achievement thus, has a great influence on a student's self-esteem, motivation, and determination in higher education. Student's poor academic performance or obtaining lower grades may result in intolerable levels of student satisfaction and leads to cost of education (American Journal of Educational Research, 2014). Hence, students' academic performances have always been a matter of interest to educators and researchers and as such they investigate the variables that contribute to academic excellence. Many researchers have identified demographic, socio-economic, family and school factors as variables contributing to students' academic performance (American Journal of Educational Research, 2014).

Academic performance, according to the Cambridge University Reporter (2014), is defined in terms of examination performance. In this study, academic performance was characterized by the overall performance in each year which ends in a Grade Point Average (GPA). The GPA score would take into account the student's performance in tests, course work and examinations.

In Ghana, the value of education is given more attention through the introduction and implementation of Free Compulsory Universal Basic Education (FCUBE). In addition, the government has put in place useful strategies-to encourage enrolment, daily attendance and retention of students in schools across the country in an attempt to realize the objectives of the FCUBE policy as well as the provision of Education for All (EFA) agenda. These strategies include the provision of school pupils with teaching and learning materials, school uniforms, the school feeding programme and the introduction of the capitation grant per every child enrolled in school. The government has also instituted best teacher awards and other teacher career development 
programmes as motivation for teachers to ensure the delivery of quality education to children (Ministry of Education, Science and Sports (MOESS), 2007). In spite of these achievements, the education sector continues to face many challenges. According to ISSER (2008), the performance of many children is failing to meet the minimum learning requirements and to acquire basic skills and competencies. This challenge does not only exist at the basic and secondary levels but also at the tertiary level as well.

At the tertiary level, students' performance is considered a vital element of education, hence stakeholders have initiated efforts to tackle it. For example, Anamuah-Mensah (2010), an educationist, attributed the phenomenon of non-performance of students to lack of effective supervision and monitoring in school, lack of motivation for lecturers and inadequate number of qualified lecturers in specialised areas. Also, Etsey (2005) attributed the cause of poor academic performance in the Shama Sub-Metro of Shama Ahanta East Metropolitan Assembly (SAEMA) in Ghana to a combination of factors relating to the school environment, teachers, students and parents. In the same vein, Diaz (2003) found factors such as intellectual ability, poor study habit, achievement motivation, lack of vocational goals, low self-concept, low socio-economic status of the family, poor family structure and anxiety as contributing to educational performance. However, poor academic achievement in school may be the result of interplay of several factors. It is therefore important not only to carry out an empirical study on the causes of low academic performance, but also to look for opportunities and propose measures to assist on-going efforts at improving students' academic achievement in general.

Although tertiary education in Ghana has attracted foreign students and received commendations for quality, the academic performance of students in the various universities has recently come under the spotlight for a number of reasons. While some educationists link this phenomenon to lecturing factors (Ankomah et al., 2005), others simply blame the schools as well as students. Aside, high failure rates are costly to all stakeholders since the essence of university education is negatively affected. This increases the cost of training graduates as well as reducing admission opportunities for high school students seeking university education. Low pass rates impose a huge cost to sponsors or parents in terms of the low number of students graduating and the reduced intake of potential students due to shortage of spaces caused by low outcomes. Much of the attrition that reduces completion rates can be attributed to low academic performance in early pre-requisite undergraduate courses (Scott \& Graal, 2007).

Class size is one of the factors that impact upon academic performance and the general relationship is a negative one (Heinesen, 2010), as such a vicious cycle seems to have been created. It is important, therefore, that an investigation be carried out to identify some of the factors that are closely associated with poor academic performance so that corrective measures, where possible, can be taken. Whereas, a number of studies have been carried out to identify causal factors of poor academic performance in a number of institutions worldwide, most of these studies focus on the three elements that intervene, that is, parents (family causal factors), teachers (academic causal factors), and students (personal causal factors) (Diaz, 2003). The combination of factors influencing academic performance, however, varies from one academic environment to another, from one set of students to the next, and indeed from one cultural setting to another.

Hoyle (1986) argues that schools are established with the aim of imparting knowledge and skills to those who attend them. According to Ankomah et al (2005), high academic performance, as measured by the examination results, is one of the major goals of a school. Behind all this is the idea of enhancing good academic performance (Mankoe, 2002). Even though Ghanaian public schools are equipped with professional teachers, their contribution to high student performance has been questioned (Ankomah et al. (2005). In relation to the UDS Wa Campus where the study is situated, for three successive academic years, from 2013/2014 to 2015/2016 , the Campus produced a total number of $\mathbf{7 4 2 5}$ graduates from all the three faculties namely Faculty of Integrated Development Studies (FIDS), Faculty of Planning and Land Management (FPLM) and School of Business and Law (SBL) (UDS Graduation Hand Books, 2014-2016). Ironically, students who got First Class Division cumulatively were only 10 representing $\mathbf{0 . 1} \%$ (See Table 1). In the 2013/2014 academic year, out of 3848 students who graduated from the Wa Campus, no one had Fist Class. The academic year 2014/2015 registered three (3) First Class Division out of 1858 graduants representing $0.2 \%$. The subsequent academic year that is, 2015/2016 also witnessed seven(7) First Class Division out of 1719 graduants representing $0.4 \%$. Comparatively, the latter results were an improvement of the 2014/2015 academic year results. As indicated in Table 1.below, it can be observed that the number of First Class graduates comparative with the total number of students who graduated during the period under review was very low. It is against this background that this paper sought to explore the possible contributory factors to the Wa Campus limited First Class situation. 
Table. 1: Summary of Undergraduate Output from 2013/14 to 2015/2016 Academic Years

\begin{tabular}{|c|c|c|c|c|}
\hline Faculty & $\begin{array}{l}2013 / 2014 \\
\text { Academic Year }\end{array}$ & $\begin{array}{l}2014 / 2015 \\
\text { Academic Year }\end{array}$ & $\begin{array}{l}2015 / 2016 \\
\text { Academic Year }\end{array}$ & Total \\
\hline \multicolumn{5}{|l|}{ FIDS } \\
\hline $1^{\text {st }}$ Class & 0 & 2 & 0 & 2 \\
\hline $2^{\text {nd }}$ Upper & 287 & 130 & 133 & 550 \\
\hline $2^{\text {nd }}$ Lower & 662 & 147 & 194 & 1003 \\
\hline $3^{\text {rd }}$ Class & 50 & 18 & 10 & 78 \\
\hline Pass & 267 & 222 & 106 & 595 \\
\hline Sub-total & 1266 & 519 & 443 & 2228 \\
\hline \multicolumn{5}{|c|}{ Planning and Land Mgt } \\
\hline $1^{\text {st }}$ Class & 0 & 0 & 6 & 6 \\
\hline $2^{\text {nd }}$ Upper & 135 & 117 & 148 & 400 \\
\hline $2^{\text {nd }}$ Lower & 519 & 180 & 217 & 916 \\
\hline $3^{\text {rd }}$ Class & 135 & 33 & 25 & 193 \\
\hline Pass & 204 & 100 & 51 & 355 \\
\hline Sub-total & 993 & 430 & 447 & 1870 \\
\hline \multicolumn{5}{|c|}{ School of Business and Law } \\
\hline $1^{\text {st }}$ Class & 0 & 1 & 1 & 2 \\
\hline $2^{\text {nd }}$ Upper & 372 & 174 & 275 & 821 \\
\hline $2^{\text {nd }}$ Lower & 897 & 374 & 425 & 1696 \\
\hline $3^{\text {rd }}$ Class & 69 & 50 & 31 & 150 \\
\hline Pass & 251 & 310 & 97 & 658 \\
\hline Sub-total & 1589 & 909 & 829 & 3327 \\
\hline Total & 3848 & 1858 & 1719 & 7425 \\
\hline
\end{tabular}

Source: UDS Graduation Handbooks 2014-2016

\section{THEORETICAL FRAMEWORK}

This section reviews literature on factors affecting academic performance. A number of factors may account for poor academic achievement in schools. In the first part of this section, the concept of academic performance is defined and its scope delineated. Other areas encompass the effects of the school environment on students' academic performance.

\section{The Concept of Academic Performance}

According to Otoo (2007) academic performance constitutes what a student is capable of achieving when he or she is tested on what he or she has been taught. It is further stated that academic performance is related to intellectual capacity. Statistics show evidence of a remarkable drop in the academic performance of Ghanaian public schools over the last decade (Etsey et al., 2005). Should it continue; the country may not be able to achieve the Sustainable Development Goal (SDG) of universal education.

\section{Grading System Used by Universities Including the UDS}

Romer (1993) found that class attendance is reflected significantly on the students' Grade Point Average (GPA). The performance of students in universities should be an issue of concern not only to the administrators and educators, but also to companies/corporations in the labour market. Academic achievement is one of the main factors considered by the employer in recruiting workers especially the fresh graduates. Thus, students have to place the greatest effort in their study to obtain a good grade in order to fulfil the employer's demand. At the UDS, students' academic achievement is measured by the Cumulative Grade Point Average (CGPA). CGPA shows the overall student's academic performance where it considers the average of all examinations' grade for all semesters during the tenure in the university. Many factors could act as barrier and catalyst to students achieving a high CGPA that reflects their overall academic performance. Again, at the UDS, students are graded on the scale of A+, A, B+, B, C+, C, D+, D and F (fail) .

UDS was established in May 1992 by the Government of Ghana to "blend the academic world with that of the community in order to provide constructive interaction between the two for the total development of Northern Ghana, in particular, and the country as a whole" (PNDC Law 279, Section 279). "The UDS was borne out of the new thinking in higher education which emphasizes the need for universities to play a more active role in addressing problems of the society, particularly in the rural areas" (UDS, 2016). The University by its mandate and constituency has a pro-poor focus. This is reflected in its methodology of teaching, research and outreach services. The specific emphasis on practically-oriented, research and field-based training is aimed at 
contributing towards poverty reduction in order to accelerate national development. With multi- campus spread in three admistrative regions in Northern Ghana, its vision is pro-poor aimed at addressing the conditions and structural causes of poverty. To achieve this, the University recruits qualified staff whose performance will propel the institution to attain this vision.

The University for Development Studies has seen lecturers, heads of department and administrative staff retire at increasing rates. To fill these roles, management must make strategic decisions to identify the key successors. When it comes to administrative staff, identifying existent staff with high talents and high performance rates is considered as the most strategic approach for the future growth and excellent management of the university. The Wa Campus is unique among the other campuses of the University in terms of number of students and workload.

However, the UDS grading system can be likened to that of Malaysia, where researchers evaluate the student academic performance based on academic performances which are cumulative grade point average (CGPA), grade point average (GPA), tests and others (Ervina and Othman, 2005; Manan and Mohamad, 2003 and Agus and Makhbul, 2002). In addition, a study in the United States by Nonis and Wright (2003) also evaluate student performance based on CGPA.

\section{Effects of School Environment on Students Academic Performance}

Research supports the fact that student performance depends on different socio-economic, psychological and environmental factors. The findings of research studies show that student performance is affected by different factors such as Learning Environment and Students' Role Performance.

Barry (2005) holds the view that, a student's educational outcome and academic success are greatly influenced by the type of school they attend. The school one attends is the institutional environment that sets the parameter of a student's learning experience. Depending on the environment, a student can either close or open the doors that lead to academic achievement. A learning environment that is free of barriers, or obstacles or distractions such as noise and gas/smoke pollutions among others can constitute health hazards, which in turn affect or reduce the student's concentration or conceptual focus to learning (Basil, 2007). According to Basil (2007), markets and garages located near schools have always posed a threat to students. Noise and pollution from these sources have always endangered students' life and concentration. Therefore for an effective learning and high academic performance, schools in both rural and sub-urban and urban areas should be located off zones characterized with smoke/gas pollutions, market centres or garages, as conducive learning environments stimulate learning, understanding and high perception.

Crosnoe, Johnson, and Elder (2004) have suggested that school sector (public or private) and class size are two important structural components of schools. Private schools tend to have better funding and smaller class size than public schools. The additional funding of private schools leads to better academic performance and more access to resources such as computers, which have been shown to enhance academic achievement (Eamon, 2005). Smaller class size creates more intimate setting and therefore can increase teacher-students bonding which has also been shown to have a positive effect on students' success.

According to Danesy (2004), other factors that compliment environmental and socio-economic factors to produce high academic achievements and performance include good teaching, counselling, good administration, good seating arrangement and good building. Danesy (2004) added that dilapidated buildings, lacking mentally stimulating facilities that are characterized with low or no seating arrangements will also be destructive.

Danesy (2004) further indicates that an innovative environment does stimulate head start learning and mental perception. It has also been proved that students who come from simulative environments with laboratory equipment or those that are taught with rich instructional aids and pictures perform better than those trained without them (add source). Thus, teaching and learning should be done under organized, planned, and fortified environment with learning instructional aids to stimulate students' sense of conception, perception and concentration to facilitate systematic understanding and acquisition of knowledge in them.

A number of studies have also been carried out to identify and analyse the numerous factors that affect academic performance in various centres of learning. Their findings identify students' effort, previous schooling (Siegfried \& Fels, 1979; Anderson \& Benjamin, 1994), parents' education, family income (Devadoss \& Foltz, 1996), self-motivation, age of student, learning preferences (Aripin, Mahmood, Rohaizad, Yeop, \& Anuar, 2008), class attendance (Romer, 1993), and entry qualifications as factors that have a significant effect on students' academic performance in various settings. The utility of these studies lies in the need to undertake corrective measures that improve on the academic performance of students, especially in public- funded institutions. The outcome or results of public-funded institutions is under scrutiny especially because of the current global economic downturn which demands that governments improve on efficiency in financial resource allocation and utilization.

Although there has been considerable debate on the determinants of academic performance among educators, policymakers, academics, and other stakeholders, it is generally agreed that the impact of these 
determinants varies (in terms of extent and direction) with context, for example, culture, institution, course of study among others. Since not all factors are relevant for a particular context, it is imperative that formal studies be carried out to identify the context-specific determinants for sound decision making. This literature review provides a brief examination of some of the factors that influence academic performance. The choice of factors reviewed here was based on their importance to the current study.

\section{Class Attendance and Academic Performance}

Romer (1993) is one of the first few authors to explore the relationship between student attendance and examination performance. A number of factors have contributed to declining class attendance around the world in the last 15 years. The major reasons given by students for non-attendance include assessment pressures, poor delivery of lectures, timing of lectures, and work commitments (Newman-Ford, Lloyd \& Thomas, 2009). In recent times, students have found a need to seek employment while studying on a part-time basis. The use of information technology also means that information that used to be obtained from sitting through lectures can be obtained at the click of a mouse.

Indeed, web-based learning approaches have become the order of the day. Given all these developments that either make it impossible or unnecessary for students to attend classes, the question that needs to be asked is whether absenteeism affects students' academic performance. Research on this subject seems to provide a consensus that students who miss classes perform poorly compared to those who attend classes (Devadoss \& Foltz, 1996; Durden \& Ellis, 1995; Romer, 1993; Park \& Kerr, 1990; Schmidt, 1983). Based on these findings a number of stakeholders have called for mandatory class attendance.

Although the existing evidence points to a strong correlation between attendance and academic performance, none of the studies cited above demonstrates a causal effect. The inability of these cross-sectional studies to isolate attendance from a myriad of confounding student characteristics (e.g. levels of motivation, intelligence, prior learning, and time-management skills) is a major limiting factor to the utility of these findings (Rodgers \& Rodgers, 2003). Durden and Ellis (1995) controlled for student differences in background, ability and motivation, and reported a nonlinear effect of attendance on learning, that is, a few absences do not lead to poor grades but excessive absenteeism does.

\section{Conceptual Framework}

According to Gratton and Jones (2010) the conceptual framework describes and explains the concepts to be used in a study. Brinthaupt and Lipka (1992) also define the conceptual framework as the theoretical structure which determines the organization of the entire research. The conceptual framework is a model that is developed upon completion of a theoretical and empirical analysis of literature. It serves as a guide to the researchers in analysing the variables in this study. Very often, a conceptual framework comprises independent and dependent variables. The dependent variables are the outcome variables that result due to an input of the independent variables. Thus, the independent variables influence the nature of the output of the dependent variables. The independent and dependent variables for the study are listed below:

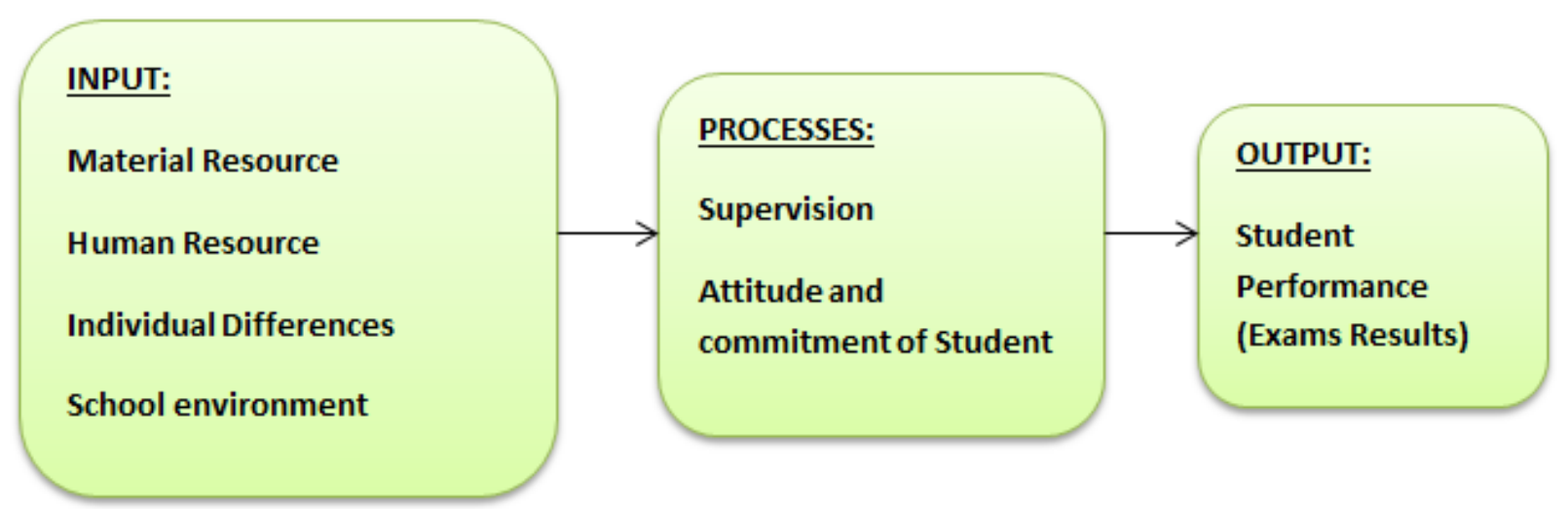

Figure 1: Conceptual Framework

Source: Author's Construct, 2017

As Figure 1 shows, the first element of this study's conceptual framework are inputs which comprise human resources, material resources, and individual student differences. Together, these inputs pass through the processes of discipline, home and parental attitude and supervision. Finally, the manner in which processes are managed determine the output that is the performance. 


\section{METHODOLOGY}

Study locality

UDS Wa Campus is one of the four Campuses of the University for Development Studies. Wa Campus is located in $\mathrm{Wa}$, the capital of Upper West Region and has three main faculties namely, Faculty of Integrated Development Studies (FIDS), Faculty of Planning and Land Management (FPLM) and School of Business and Law (SBL). Wa Campus offers various Diploma, Graduate and Postgraduate programmers. Wa Campus over the years has produced a number of graduates, with limited First Class Division. This has challenged the researcher to explore the possible factors to the Wa Campus situation.

\section{Research Design}

This study adopted the case study design with the view to explore the possible causes to limited First Class Division degree classification of undergraduate students of UDS, Wa Campus. The case study design also enabled the researcher to review, process and offer interpretation to data gathered from both secondary and primary sources. Given the objective of the study, a qualitative case study design was adopted as opposed to other qualitative research designs. Robson (2002), indicates that a case study involves an empirical investigation of a particular contemporary phenomenon within its real life context using multiple sources of evidence. Babbie and Mouton (2004) asserted that a case study may be conducted for the purpose of describing, exploring and explaining. Thus, a case study could be descriptive, explorative and explanative. Leedy and Ormrod (2010) opined that a case study may be especially useful for learning more about a little known or poorly understood situation. The contributory factors that influence academic performance demand in-depth understanding. Ironically, these factors that account for limited First Class Division on Wa Campus are largely poorly understood. This justifies the choice of the qualitative case study design which enabled the researcher to gain much insight into the problem at stake.

\section{Target Population and Selection of Respondents}

This study targeted past students, seventeen of whom are currently employees of UDS working on UDS, Wa Campus. In this regard, purposive sampling technique was used to select 15 available and willing respondents across the three faculties on the Wa Campus. In all, seven lecturers, six administrative staff and two security officers were selected for the study. Female respondents were four (4) whilst that of males were eleven (11). Besides, two other key informants knowledgeable in the development of UDS, Wa Campus were also selected purposely bringing the total number of respondents to 17 as found in Table 2 .

\section{Table. 2: Summary of selected Respondents}

\begin{tabular}{|l|l|l|l|}
\hline Units & Male & Female & Total \\
\hline Lecturers & 6 & 1 & 7 \\
\hline Administrative staff & 3 & 3 & 6 \\
\hline Security Personnel & 2 & 0 & 2 \\
\hline Key Informants & 2 & 0 & 2 \\
\hline Total & $\mathbf{1 3}$ & $\mathbf{4}$ & $\mathbf{1 7}$ \\
\hline
\end{tabular}

Source: Field Study, 2017

\section{Data Sources and Analysis}

The study made use of both primary and secondary sources of information. Primary data were generated through interview with the aid of interview guides and audio recording device. In all, 17 interview sessions were held on the Wa Campus which each lasted averagely 18 minutes between February, 2017 and March, 2017

Primary data were complemented by secondary data. Notable among the secondary sources reviewed were the UDS Graduation Handbooks. The information from the two sources enabled the researcher have a holistic view of the problem as prevailed on Wa Campus. Data gathered were analysed descriptively. Recorded data were first transcribed and carefully edited and categorized into themes.

\section{RESULTS AND DISSCUSSION}

The study aimed at finding out the factors that influence the limited First Class Division degree classification achieved by students on Wa Campus of UDS. Six broad but interconnected factors were suggested by the respondents as the main causes of the limited First Class Division on Wa Campus as captured by Table 3 below. 
Table. 3: Possible factors influencing limited First Class Division

\begin{tabular}{|l|l|l|}
\hline Contributory factors & Frequency & Percentage \% \\
\hline Poor lesson preparation and delivery by lecturers & 13 & 26.53 \\
\hline Irregular attendance of lectures by lecturers & 7 & 14.28 \\
\hline Overcrowded lecture halls with inadequate teaching aids & 12 & 24.48 \\
\hline Poor lecturing schedule time & 7 & 14.26 \\
\hline Poor library facilities & 4 & 8.16 \\
\hline Poor student attitude to learning & 6 & 12.24 \\
\hline Total & 49 & 100 \\
\hline
\end{tabular}

Source: Field Study, 2017

\section{Poor lesson preparation and delivery}

Data gathered revealed that poor lesson preparation and delivery on the part of lectures were a major contributory factor to the limited First Class Division awarded to deserving students on Wa Campus. This registered 13 responses representing $26.5 \%$ of identified factors. Technical knowledge is important just as professional teaching pedagogy. As noted by Boating (2003), the success or failure of curriculum delivery depends on the teacher or lecturer. The lecturer is the pivot of the education system as he or she makes or breaks the education programmes, delivers the objectives of education reforms, and is the engine of everything that is planned and implemented in the university. However, as the study revealed, some of the respondents intimidated that lessons are poorly prepared and delivered which affect students' performance. This is what one respondent remarked during an interview in March, 2017:

Most lecturers failed to prepare their lessons well and also delivered these ill-prepared lessons poorly. In most instances, students became more confused than the state in which they were before attending lectures. My close friend constantly questioned whether it was a curse to attend lectures. In fact, we need to do something about the way most lecturers handle their respective courses. This to me is the reminiscence of the limited First Class Division achievement on Wa Campus (An Informant's Remark, 2017).

A key informant supported what was given by the respondents and expressed that students have been complaining about the poor delivery of some lecturers. This is what the key informant said:

I think we need to give periodic in-service skill training to our lecturers on effective lesson preparation and delivery. Our learning environment is not the best and in a situation where lecturers fail to deliver effectively, it affects learning and students' academic performance' (Key Informant Interview, March 2017).

\section{Irregular attendance of lectures by lecturers}

A major factor which enhances learning is regular attendance and timely delivery of lessons. Seven (14.2\%) respondents expressed that the limited First Class Division could be attributed to irregular attendance on the part of lecturers. A respondent stated:

Some lecturers will not attend lectures as per the time table. Students will struggle to go to the Campus only to be told that the lecturers are not in. They often arranged lectures at the displeasure comfort of students. Ironically, they will dump all forms of reading materials on students at the close of examination.

How do you expect students to do well in such learning condition? ( Respondent Interview, 2017).

Looking at human resources, lecturers, supervisors, heads of department form the pivot around which the wheel of education moves. The periodic absenteeism which affects learning and performance as identified in this study supports the works of Oduro and MacBeath (2003) when they asserted that in Ghana, teacher absenteeism, is a persistent concern which impedes high performance.

\section{Overcrowded lecture halls with inadequate teaching aids}

Danesy (2004) indicates that the innovative environment stimulates head start learning and mental perception. It has also been proved from the study and Danesy (2004) that students who come from simulative environments with laboratory equipment or those that are taught with rich instructional aids and pictures perform better than those trained without them. Apparently the study revealed the contrary on UDS, Wa Campus. Twelve $(24.5 \%)$ respondents were of the view that the environment stifles effective learning. This is what two respondents said respectively:

'Our lecture halls are overcrowded. And as if this is not enough, there are no teaching aids such as public address systems and projectors. Lecturers have to shout during lectures to reach students but to no avail. The situation is worse of when it comes to students using the corridors and verandas due to the limited space in the lecture halls. In fact, in some situation I wandered whether we were in nursery school. All the same, we struggled to get a better grade not First class any way'. (Respondent Interview, 2017). 
'The teaching and learning environment was not friendly at all. Students sat in compact lecture halls to extent that it was difficult leaving the halls to attend to either nature's call or to urinate. 'In most instances the lightening situation was not good. When lectures extended to the night, you would wander as to how we conducted our teaching and learning in this university. I wanted to get a tertiary certificate and so amidst this situation I made an honourable grade but not First Class' (Respondent's Interview, 2017).

The information gathered from the respondents was confirmed by the key informants. This is what one of them said:

'You know we began this Campus with quite limited infrastructure. I can tell you the infrastructure situation is better now than before. This is not to rule out that we do not have some challenges pertaining to lecture halls. In as much as possible, we try to manage the situation especially at the time that we received large chunk of students. The infrastructure situation affects teaching and learning but it is not the only cause of limited First Class on our Campus. We all need to play instrumental role to improve the performance of students. Lecturers, management, students, the government and philanthropists must all play their honest part. Anyway, the benchmark of any tertiary education is quality education but not automatic First Class Division' (A Key Informant Remark, 2017).

The findings from this study buttress the work of Crosnoe, Johnson, and Elder (2004) who have suggested that improved infrastructure with reasonable class size promotes quality teaching, learning and performance.

\section{Poor lecturing schedule of time}

The study revealed that poor lecturing schedule of time is another contributory factor to the problem at stake. Seven respondents in a similar view indicated that time tables are prepared which do not support effective learning. A respondent said:

'Imaging using 30 minutes after a lecture to travel from Bamahu Campus to attend another lecture at 36 Unit Block.which is about ten kilometers. Stress and tiredness feed into the learning situation. In our time, students have to struggle to get means of transport from town to attend lectures especially at Bamahu. By the time we closed from lectures, we were already weak to do any serious studies. We therefore relied on our lecture notes without getting any deeper knowledge from other sources. This I think has contributed to the limited First Class situation over the years'.

A key informant supported the respondents but indicated that given the limited lecture halls, the best practice was done, that is, commuting from Bamabu and the 36 Unit Block

\section{Poor library facilities}

Learning materials play an instrumental role in quality education and performance. As noted by Ministry of Education (MOE, 1994), material resources such as books, stationery, furniture, equipment and recreational facilities are vital to effective education. Four respondents representing $27 \%$ were of the opinion that inadequate library facilities on Wa Campus amidst the sheer number of student population contributes to poor academic performance. Even though the number of respondents who said this was only four, this cannot be dismissed as such. In relative terms, the library facilities on Campus do not match the number of students. What this means is that those who will like to use the library at a particular time period but due to the limited space may be denied the opportunity given the fact that the library can only take less than 150 students at a time compared to 7425 students on the Campus.

A key informant admitted that the library facilities on Campus have limited space in comparison with the student population. He however, said that most students do not even patronize them and n many occasions the libraries are empty. Five of the respondents agreed to what the key informant said and was also collaborated by the Campus Liberian.

\section{Poor student attitude to learning}

Seven respondents attributed limited First Class Division to poor students' attitude to learning. Quality education is a shared responsibility and in a situation when students fail to play their role, this will undermine effective performance. As indicated by one respondent:

Some students fail to attend lectures. They are more interested in social gathering than academic issues.

Lectures are sometimes empty but become full when students get to know that there is mid trimester exams. Apparently, students expect First Class and other better grades. We need to impress upon students the need to take their studies seriously as First Class grade is achieved on merit' (An Interview with a Respondent, 2017).

The findings suggest that students have to be disciplined in terms of their studies. According to Awulugutu (2006), discipline and commitment is the master of one's hopes and aspirations without which, one cannot make any significant progress in life. Awulugutu (2006) goes on to observe that discipline is the key that unlocks the 
door to wealth, happiness, and success, and turns one's dream into reality. In school, if students allow discipline to rule their lives, they will become what they want to become in future. It is also noted that in every aspect of life, discipline is the facilitator that helps break down barriers between the individual and his or her goals (Awulugutu, 2006). The efforts to produce more First Class students on UDS, Wa Campus demand that students should commit themselves to careers they have carved for themselves.

\section{Recommendations}

The study recommends the following:

The Ministry of Education (MOE) should support teaching and learning by providing teaching and learning resources to all educational institutions. Additionally, the UDS Management should provide all necessary infrastructure and equipment for effective practical training of the students.

The University Management should organise regular workshops and in-service training to introduce all lecturers periodically to more effective teaching strategies. Heads of Department should also monitor and appraise lecturers input by students' performance in their respective courses.

The University Management should ensure that lecturers teach their respective specialist subjects so that their students will understand what they are taught. This may affect the number of first classes generated yearly. The academic Planning and Quality assurance Directorate of the University, Deans and Heads of Department should ensure that instructional resources such as projectors, public address system and internet facilities are provided at the lecture rooms to facilitate teaching and learning.

Government agencies, NGOs, University Management Committees and other stakeholders engaged in development of school programmes and provision of school infrastructure should provide technical assistance and/or other alternatives to lecture rooms (formal) learning which does not favour all students.

Finally, an effective reward system should be established by the University in order to reward students who are awarded First-class Degrees

\section{Conclusion}

The major conclusion drawn from this study is that, the identified differences between the UDS and other educational institutions from the literature review have to be resolved through adequate resourcing, improvement in infrastructure, development of teacher competency, recruitment of experience and qualified lecturers, in order to address the differences and enhance academic achievement of students. Also, lack of teaching and learning materials places serious limitations on knowledge and skills acquisition of students. This may lead to poor performance. Students also have a role to play by taking their studies seriously by attending lectures regularly and participating fully in all educational activities

\section{References}

Anamuah-Mensah, J., \& Benneh, M. (n.d.).(2010) Particular issues of teacher education in Ghana (High level expert meeting on UNESCO).

Awulugutu, R. K. (2000). "Discipline the master key of success". The Mirror, March, 04/03/2006, p.37

Ankomah, Y. A., Koomson, J. A., Bonsu, R S., \& Oduro, G. K. T. (2005). "A review on the concept of quality in education: Perspective from Ghana Ed Qqual working Paper No. 1"

Agus, A and Makhbul, Z.K. (2002). An empirical study on academic achievement of business students in pursuing higher education: An emphasis on the influence of family backgrounds. Paper presented at International Conference on the Challenges of Learning and Teaching in a Brave New World: Issues and Opportunities in Borderless Education. Hatyai Thailand

Anderson, G., \& Benjamin, D. (1994). The determinants of success in university introductory economics courses. Journal of Economic Education, 25(2), $99-119$.

Aripin, R., Mahmood, Z., Rohaizad, R., Yeop, U., \& Anuar, M. (2003). Students' learning styles and academic performance. 22nd Annual SAS Malaysia Forum, 15th July 2008, Kuala Lumpur Convention Center, Kuala Lumpur, Malaysia.

Babbie, E., and Mouton, J. (2004). The Practice of Social Research. Cape Town: Oxford University Press Southern Africa.

Boateng, T. A. (2003). "Factors affecting academic performance of students in some selected Junior Secondary Schools in the Kumasi Metropolis". Unpublished

Brinhaupt T. M.\& R. P. Lipka (1992) Development of K-8 Teachers' Knowledge and the Transition from University Student to Professional

Basil, S. R. (2005). Socioeconomic status and academic achievement: A meta-analytic review of research. Review of Educational Research, 75(3), 417 - 453.

Crosnoe,. Johnson \& Elder, (2004). Factors affecting academic performance of students: A case of secondary School level: Oxford University Press Southern Africa. 
Danesy S. F. (2004). Predictors of student academic performance in the introductory marketing course. Journal of Education for Business, 73 (5), $302-307$.

Diaz, A. L. (2003). Personal, family, and academic factors affecting low achievement in secondary schools. Electronic Journal of Research in Educational Psychology and Psychopedagogy, 1(1), 43 - 66.

Durden, G. C., \& Ellis, L. V. (1995). The effects of attendance on student learning in principles of economics. American Economic Review, 85(2), 343-346.

Devadoss, S., and Foltz, J. (1996). Evaluation of Factors Influencing student's attendance and Performance. American Journal of Agricultural Economics, 78(3), Eamon, R. (2005), The relative social class of a student body also affects academic achievement. Oxford University Press Southern Africa.

Emy Indaryani, Hartati Muchtar and Diana Nomida Musnir. Application of Performance Assessment in Competence Learning and Test in Beauty Program Vocational School, - SMKN 3 Bogor. American Journal of Educational Research. 2014; 6(10):1372-1378. doi: 10.12691/education-6-10-6

Ervina and Othman, (2005), The Factors Influencing Students' Performance at Universiti Teknologi MARA Kedah, Malaysia

Etsey (2005) attributed the cause of poor academic performance in the Shama Sub-Metro of Shama Ahanta East Metropolitan Assembly. (SAEMA)

Gratton, C., \& Jones, I. (2010). Research Methods for Sports Studies. London: Taylor \& Francis

Heinesen, E. (2010). Estimating class-size effects using within-school variation in subject- specific classes. The Economic Journal, 120(545), 737 - 760 .

Hoyle, E. (1986). Policies of school management. Suffolic: The Press Ltd.

Jannifer Barry (2005), The Effect of Socio-Economic Status on Academic Achievement: Unpublished Thesis

Leedy, P.D, and Ormrod, J.E. (2010). Practical Research, Planning and Design. Boston: Pearson Education, Inc.

Mankoe, J. O. (2002). Educational administration and management in Ghana. Madina Accra: Progressive Stars Limited

Moess (2007) ACL '07 Proceedings of the 45th Annual Meeting of the ACL on Interactive Poster and Demonstration Sessions, Pages 177-180

Ministry of Education (2007). "The new structure and content of education of Ghana", Accra.

Manan, S.K. \& Mohamad, R. (2003). Kajian mengenai pencapaian akademik pelajar-pelajar di UiTM Shah Alam: Satu analisa perbandingan antara jantina. Social and Management Research Journal. Vo 11 No 1 .

Nonis \& Wright, (2003); Wright \&. Mischel, 1987), performance is a multi- plicative function of both ability and motivation. Performance $=$ Ability $\times$ Motivation: Oxford University Press Southern Africa.

Newman-Ford, L., Lloyd, S., \& Thomas, S. (2009). An investigation in the effects of gender, prior academic achievement, place of residence, age and attendance on first-year undergraduate attainment. Journal of Applied Research in Higher Education, 1(1), 13 - 28.

Otoo, D. (2007). Comparative study of academic performance of public and private J.S.S graduates: A case study of selected schools in the Kumasi Metropolis.Unpublished

Oduro G. K. T., \& MacBeath, J. (2003). Traditions and tensions in leadership: The Ghanaian experience.Cambridge Journal of Education. 33, (3), 442-455.

Park, K. H., \& Kerr, P. M. (1990). Determinants of academic performance: A multinomial logit approach. Journal of Economic Education, 21(2), 101-111.

Robson, C. (2002). Real World Research. Oxford: Blackwell.

Rodgers, J. R., \& Rodgers, J. L. (2003). An investigation into the academic effectiveness of class attendance in an intermediate microeconomic theory class. Faculty of Commerce - Papers, University of Wollongong, N.S.W., 2522 Australia. Accessed on November 02, 2011 from http://ro.uow.edu.au/commpapers/174

Romer, D. (1993). Do students go to class? Should they? Journal of Economic Perspectives, 7(3), $167-174$.

Schmidt, R. (1983). Who maximizes what? A study in student time allocation. American Economic Review, 73(2), 23-28.

Scott, J., \& Graal, M. (2007). Student failure in first year modules in the biosciences: and interview based investigation. Bioscience Educational ejournal 10. Accessed on November 02, 2011 from http://www.bioscience.heacademy.ac.uk/journal/vol10/beej-10-c2.pdf

Siegfried, J., \& Fels, R. (1979). Research on teaching college economics: A Survey. Journal of Economic Literature, 17(3), $923-939$.

Sifuna, D. N \& Otiende, J.E. (1980). An Introductory History of Education. Nairobi: Nairobi University Press. 